\title{
St. Philippe Rescue Center in an Area of high Prevalence of HIV Infection in Kisumu and Street Work for Street Boys in Nairobi
}

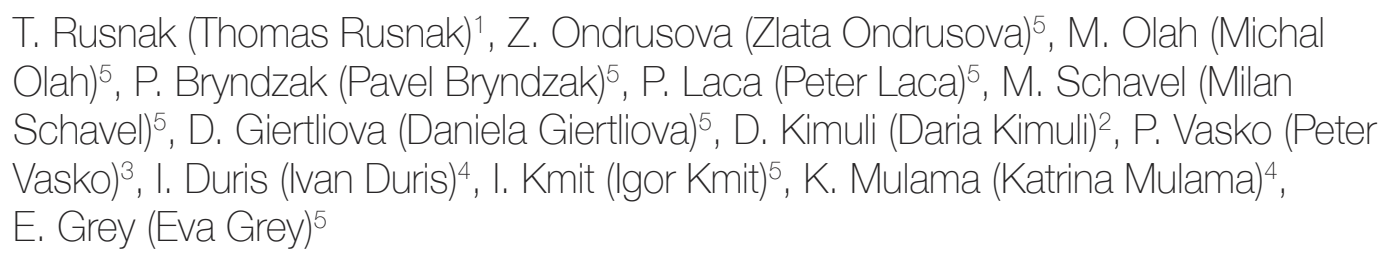

${ }^{1}$ St. Philippe Neri Rescue Centre SEU University Anti-malnutritional Program Kisumu, Kenya.

${ }^{2}$ St. Philippe Neri School Joshka, St. John Paul II School of Missiology SEU Bratislava in Joshka, Kenya.

${ }^{3}$ Oasis of peace love and mercy, Nairobi, Kenya.

${ }^{4}$ Dr.David Roden Tikit Mission health centre, West Pokot, Kenya.

${ }^{5}$ Dept. of Tropical Diseases, Slovak Medical University Bratislava, Slovakia.

\section{E-mail address:}

frolinek@gmail.com

\section{Reprint address:}

Tomas Rusnak

St. Philip Neri rescue center

P. O. Box 68

40100 Kisumu

Kenya

Source: Clinical Social Work and Health Intervention

Volume: 12

Issue: 1

Pages: $20-22$

Cited references: 2

\section{Reviewers:}

Vitalis Okoth

Hargeisa, Somalia

Johnson Mawole

Nyanza, Tanzania

\section{Keywords:}

Street boys. HIV.

\section{Publisher:}

International Society of Applied Preventive Medicine i-gap

CSWHI 2021; 12(1): 20 - 22; DOI: 10.22359/cswhi_12_1_04 CC Clinical Social Work and Health Intervention 


\section{Abstract:}

\section{Introduction}

Street boys in slums of large African Urban settings such as Kibera in Nairobi or Soweto in Johannesburg are probably the largest concentrations of youth associated social pathology worldwide. Here we present two examples of effective street work programs: one in Kisumu, focused on the strategy to bring the children from street to school and sports, in a large HIV prevalence City of Kisumu; and vice versa, an street work program focused on narcotic cessation as an exchange for food and potential sheltering in one of the largest slums in Africa in Kibera, Nairobi.

\section{Settings and Methods}

Kisumu is a town in the highest endemic area for HIV and malaria. Near Lake Victoria, in Western Kenya it has a population of up to 150,000 ; Nairobi has more than 10 million, with at least 6 large slum areas the largest in Kibera with about 950,000 people living in critical housing and poverty conditions. First setting in Kisumu is using full board shelter to attract street boys including sport and education. A second project is using food and potential upgrade to their community for those who voluntary accept the cessation of glue, gasoline or other inhalational substance use.

\section{Results and Discussion}

The spectrum of social pathology and three major killer diseases is in table 1. As in Kisumu, substance use is less frequent but HIV and Malaria common. In Nairobi crime and substance inhalational use is more common. Due to altitude, malaria is less frequent and Hiv under better control due to active screening by the government and NGOs.
Table 1: Spectrum of Social Pathology in two sites ofactive social intervention for street boys

\begin{tabular}{|lll|}
\hline Social pathology & Kisumu & $\begin{array}{l}\text { Nairobi } \\
\text {-Kibera }\end{array}$ \\
\hline Substance inhal.use & rare & frequent \\
\hline Illiteracy & common & less \\
\hline Malnutrition & less & common \\
\hline Crime & less & common \\
\hline HIV malaria & more & less \\
\hline Tuberculosis & less & more \\
\hline
\end{tabular}

The worst stages of substance inhalational abuse - so called gasoline and glue dementia may be seen in Nairobi slums, where the number of street boys may exceed 100,000 and therefore street work is more dangerous for social workers. Sports and education is offered to those willing to join the St. Philippe Neri Community in Kisumu.

\section{Conclusion}

Motivational street work with incentives such as food, shelter, day center created hygiene, sports, education is an important factor to improve the motivation of street boys for a better future. Very important. if not crucial. is also the pastoral work and offer of various religious services for this vulnerable group of population.

\section{References}

1. PROCHAZKOVA K., KOVAC R, OLAH M et al (2018) High threshold shelters in an urban large setting, Clinical Social Work Journal, 2018. 9. 44.

2. PERI H A, SUBRAMANIAN S, SLADECKOVA V, BYDZOVSKY J, DURCOVA B, 
KUBALIKOVA Z, OLAH M, MATULNIKOVA L, DOKTOROV A, BERESOVAA, KUBIK F, FULA M, OTRUBOVA J, KALATOVA D, KUKUCKOVA E, JURINOVA S, BENCA J, SHAHUM A, HOY LEANG HOINAND CHENG HOIN, SETA S/ Early detection of adverse therapy reaction in orphan children with AIDS (short communication) / In: Acta Missiologica. - ISSN 13377515. - Vol. 13, no. 2 (2019) p. 184-187. 